\title{
The Efficiency Performance of Global Islamic Banks
}

\author{
Norlina Kadri, Rossazana Ab-Rahim \& Dyg Siti Zahrah Abg-Abdillah \\ Faculty of Economics \& Business, Universiti Malaysia Sarawak
}

\begin{abstract}
This paper examines the efficiency performance of the Islamic banks that consist of 14 countries namely Bahrain, Bangladesh, Iran, Jordan, Kuwait, Lebanon, Malaysia, Pakistan, Qatar, Saudi, Tunisia, Turkey, UAE, and Yemen during the period of 2004-2011 with 44 Islamic banks involved. The efficiency estimates of individual banks are evaluated using the Data Envelopment Analysis (DEA) approach. The empirical findings suggest that during the period of study, pure technical efficiency outweighs scale efficiency in the global Islamic banking sector implying that the Islamic banks have been managerially efficient in exploiting their resources to the fullest extent. The empirical findings seem to suggest that the global Islamic banks have exhibited high pure technical efficiency. During the period of study it is found that pure technical efficiency has greater influence in determining the total technical inefficiency of the Global Islamic banking sectors.
\end{abstract}

\section{INTRODUCTION}

The Islamic banking assets with commercial banks had globally reached USD1.54 trillion in 2012 and set to cross USD1.7 trillion in 2013, suggesting an annual growth of $17.6 \%$ over the last four years (EY World Islamic Banking Competitiveness Report 2013/2014). The global Islamic banking asset distribution of the rest of the world (including Iran) comprises of 60\%, Malaysia 8\%, UAE 5\%, Kuwait 4\%, Qatar 3\%, Turkey 2\%, Indonesia 1\%, Bahrain 1\%, and Saudi Arabia 16\% (Ernst and Young, 2013). The profitability of Islamic banking has reach the average return on equity of $12.6 \%$ for top 20 Islamic banks as compared to comparable conventional average of $15 \%$. Thus, Islamic banking continues to be an exciting growth story characterized by robust macro outlook of core Islamic finance market and increasing share system assets. This indicates the rapid growth and emergence of Islamic banking sectors as one of the determinants in the world's financial health.

Islamic banks are largely protected from the 2008 financial crisis (Willison, 2009; Yilmaz, 2009). Hasan and Dridi (2010) explain that Islamic banking system have highly regulated operational environment guided by Shariah principles prohibited investment in the type of instruments which adversely affected conventional banks and which influenced the crisis. Hence, Islamic financial industry was brought into the spotlight as a possible alternative for investment and banking since recent global financial crisis (Smola and Mirakhor, 2010). As an alternative banking system, Islamic banking emerged in the global landscape with the advent of Islam. Beck et al. (2013) pointed that Islamic financial institutions have a relatively high market share in several emerging markets, such as Malaysia and several Middle Eastern countries. The evolution of Islamic banking has signaled a great transformation to the financial industry, as evidence from growing numbers of new participant in Islamic bank today (Waemustafa, 2013). In simplified form, Islamic banking and finance can be defined as banking and finance in consonance with the ethos and value system of Islam. Thus, it is governed, in addition to the conventional good governance and risk management rules, by the principles laid down by the Islamic Shariah (Ayub, 2007). 
Over the past two decades, Islamic banking has shown major progress and serves as important banking industry in the world. Sole (2007) posits that Islamic banking is steadily moving into an increasing number of conventional financial systems. There are over 300 Islamic financial institutions worldwide across 75 countries. These countries including the Middle East and North Africa (MENA) ${ }^{1}$ regions, Association of South East Asian Nation (ASEAN) ${ }^{2}$, Asian Pacific, and European Countries. Saleh and Zeitun (2007) found that interesting development of Islamic banking globally. This sector has not only grown in the Muslim world, but has also gained significant attention in the Western world, with over 250 Islamic banks worldwide controlling approximately US\$400 billion in assets and client money. Although Islamic banking was initially developed to fulfil the needs of Muslims, but, observing the growth of Islamic banking assets in the global economy, it clarifies that Islamic banking has actually gaining acceptance, especially in highgrowth emerging markets, as an effective means to build an inclusive financial system and replace the shadow economy (Schneider, 2013) $)^{3}$.

Pertaining to the emergence of Islamic banking in the world financial system today, studies such as Willison and Yilmaz (2009) found that the 2008 financial crisis led to difficulties in many conventional banks across the globe, but not for Islamic banks. Islamic banks were largely insulated from the crisis. During the global financial crisis period, despite the turmoil across financial markets, Islamic banks remained relatively resilient, still able to grow at a significant pace. The balance sheets of Islamic banks were relatively unharmed as compared to their conventional peers due to the fact that demand for financial products had been essentially domestic-driven, which was helped further by banks high capitalization and high liquidity that provided a relatively higher degree of confidence to counterparties. Hasan and Dridi (2010) revealed that factors related to Islamic banks' business model helped limit the adverse impact on profitability in 2008. Moreover, Islamic banks' credit and asset growth performed better than conventional banks in 2008 and 2009, contributing to financial and economic stability. Furthermore, following the global financial crisis, Islamic banks in Asia have been able to increase their financing portfolios substantially and develop the retail Islamic banking sector to offer a more diverse range of products and services. Based on the sample of Islamic banks, the financing-to-deposit ratio (FDR) has since climbed steadily to $80 \%$ led by Malaysia and Bangladesh, despite sharp declines in Pakistan given slower financing growth. However, in the Middle East and North Africa (MENA), the FDR declined substantially in 2009 onwards as higher non-performing credits forced banks to be stricter in distributing financing. The declines were led by Islamic banks in Saudi Arabia, Kuwait and particularly Egypt in 2010 and 2011. The growth of Shariah-compliant investment opportunities has enabled Islamic banks to be more efficient in channeling funds to productive sectors. The small- and medium sized enterprise (SME) market has been one such popular target of Islamic banks (Bank Indonesia Statistic, 2011) ${ }^{4}$.

In order to be able to detect problems and settle concerns about the safety and soundness of investments for depositors, managers, and regulators alike, it is therefore essential to measure the performance of Islamic banking. Badreldin (2009) posits that it is highly important for managers to

\footnotetext{
${ }^{1}$ MENA consists of Bahrain, Egypt, Iran, Iraq, Jordan, Kuwait, Lebanon, Yemen, UAE, Libya, Morocco, Oman, Palestine, Qatar, Saudi Arabia, Syria, Tunisia, and Algeria

${ }^{2}$ ASEAN includes Malaysia, Myanmar, Thailand, Indonesia, Singapore, Laos, Cambodia, Brunei, Vietnam, Philippines. ${ }^{3}$ The shadow economy basically comprises legal business activities that are performed outside the reach of government authorities, not including illegal activities and crimes such as drug dealing, smuggling, money laundering, and embezzlement, or household enterprises that, by law do not register with the government (Schneider, 2013).

${ }^{4}$ For example, $69.4 \%$ of Shariah banks' financing activity in Indonesia as at end of 2011 (Ernst and Young, 2013). 
determine the financial position of their institution compared to their competition or industry benchmarks, as well as evaluating how effective previously taken decisions affected the bank. Islamic bank performance measurements also help Shariah Supervisory Boards and other regulators to understand the performance of banks and to ensure only transparent and clear information is available and used. Finally it helps investors to identify chances and investment opportunity and ensure that the best decision regarding use of funding is being taken

As in any banking industry, Mostafa (2011) added that measuring efficiency levels at the Islamic banks is indeed crucial for managers and investors alike. Following Anderson et al. (1998), efficient resources usage and allocation benefits consumers since this indicates lower prices and more professional services. In recent years, studies on Islamic banking efficiencies have started to grow worldwide (Darrat et al., 2002; Yudistira, 2003; Hassan, 2006; Mohamad et al., 2008; Moin, 2008; Shahid et al., 2010).Yet, there is still lack of research done to measure the cost efficiency in Islamic banking, particularly in the whole world region. In fact, in most of the studies, which type of banks acquired more cost efficiency is still unknown. Furthermore, while there are existing studies on measuring efficiency of Islamic banking, this study attempts to extend the study by estimating the cost function of Islamic banking in the world.

A healthy and efficient banking sector is deemed as a necessary condition to achieve the stability of a financial system (Tahir, Mongid, and Haron, 2012). This is because banking systems and stock markets enhance growth which is the main factor in reducing poverty of a country. Whilst there are extensive studies on conventional banking sectors efficiency, researchers have started to take particular interest to investigate the efficiency performance on Islamic banking sectors. Among the studies which measures the efficiency of banking sectors in particular, Islamic banking are Nor Hayati, Mohamad Akbar, and Sufian (2010), Haseeb et al. (2010), Efendić (2011), Tahir, Abu Bakar, and Haron (2011), Mostafa (2011), Zainal and Ismail (2012), and most recently, Shafitrana and Hosen (2014). However, most of the studies conducted are focusing mainly on single or at most two countries. Despite the rapid growth of the Islamic banking and finance industry, analysis of Islamic banking at a cross-country level is still in its infancy (Sufian and Noor, 2009). Furthermore, cross-country analysis, in particular of MENA and Asian countries, is important as most of the well-established Islamic banks are operating in these countries. Hence, this study departs from the existing studies as this study attempts to investigate the cost estimation of the global Islamic banking for all countries.

Attempts to measure the performance of Islamic banking is crucial. However, as far as this study is concerned, there are no existing studies that focus on the world Islamic Banking despite that Islamic banking had became prominent in contributing to the world economy. The Islamic banking growth continues to be positive, growing $50 \%$ faster than overall banking sector (Ernst and Young World Islamic Banking Competitiveness Report 2012/2013). Based on the data obtained from the International Monetary Fund (IMF), Islamic banking assets with commercial banks globally grew to $\$ 1.3$ trillion in 2011 . This suggests an average annual growth of $19 \%$ over the past four years, whereas in 2011 itself, it has contributed to $24 \%$ of growth. This has proven that Islamic banking has become at par with the other banking sectors in the world. Notwithstanding the importance of Islamic banking in today's economy, there are still serious lacks of empirical studies on the world Islamic banking (Iqbal, 2001). Thus, to fill the gap of lack research, this study will extend the research by focusing on the technological differences according to scale and ownership structure of Islamic banks in the world. 


\section{PAST STUDIES}

Generally, a stream of existing studies on Islamic banks had focused on comparing the efficiency of Islamic and conventional banks. Studies such as Ahmad Mokhtar, Abdullah, and Al-Habshi (2006) empirically investigate the efficiency of the full-fledged Islamic banks, Islamic windows, and conventional banks in Malaysia by adopting the intermediation approach to define the inputs and outputs. There are two inputs and one output in the study. Total deposits which consists of deposits from customers, and other banks) and total overhead expenses which include personnel and other operating expenses) are the inputs that produced output that is the total earning assets. Ahmad Mokhtar et al. (2006) discover that the efficiency of the overall Islamic banking industry has increased during the period of study while that of conventional banks remained stable over time. However the efficiency level of Islamic banking is still lower than that of conventional banks.

Mariani, Saal, and Battisti (2008) analyze the efficiency of a sample of Islamic and conventional banks in 10 countries that operate Islamic banking for the period 1996-2002, using an output distance function approach. The inputs are equity, total operating expenses, and deposits. On the other hand loans and total earning assets are the outputs. These inputs and outputs are determined by using the intermediation approach. The results suggest that Sudan and Yemen have relatively higher inefficiency while Iran and Malaysia have lower estimated inefficiency. Except for Sudan, where banks exhibits relatively strong returns to scale, most sample banks exhibit very slight returns to scale, although Islamic banks are found to have moderately higher returns to scale than conventional banks.

Mohamad (2010) aims to estimate the data envelopment analysis (DEA) efficiency scores for Islamic Banks in Saudi Arabia by defining the inputs and outputs using the intermediation approach. In the study, interest and non-interest income are the inputs while the net interest and non-interest income are the output. The results on MPI reflect an improvement in average productivity of banks. However, the major increase in productivity gains emerged through technological change relative to the efficiency change. The banks across the Kingdom appear to have succeeded in catching up with the best practices, even though the average scores on technical efficiency (TE) stood beyond optimal levels.

Mohammed Khaled et al. (2008) measures and compares the cost, revenue and profit efficiency of 43 Islamic and 37 conventional banks over the period 1990-2005 in 21 countries using Data Envelopment Analysis. It assesses the average and overtime efficiency of those banks based on their size, age, and region using static and dynamic panels. Mohammed Khaled et al. (2008) defined the inputs and the outputs of the banks using the intermediation approach because this approach is inclusive of interest and/or funding expenses, which often account for between one-half and two-thirds of total costs. Moreover, the intermediation approach may be superior for evaluating the importance of frontier efficiency for the profitability of financial institutions, since the minimization of total costs, and not just production costs, is needed to maximize profits (Iqbal and Molyneux, 2005). Hence, the inputs were defined as labor (personnel expenses), fixed assets, and total deposits and total borrowed funds. Meanwhile, the outputs were total loans, other earning assets, and off-balance sheet items. The findings suggest that there are no significant differences between the overall efficiency results of conventional versus Islamic banks. Overall, the results in this paper are favorable with the 'new' banking system. 
Taufiq Hassan et al. (2009) measures and compares the cost and profit efficiency of 80 banks in 21 of Organisation of Islamic Conference (OIC) countries: comprising of 37 conventional banks and 43 Islamic banks, using the Stochastic Frontier Approach (SFA). In addition, it assesses the efficiency of those banks based on their size, age, and region. To define the inputs and outputs of the banks, Taufiq et al. (2009) adopted the intermediation approach where labor, fixed assets, and total funds were determined as inputs, while total loans and other earning assets off-balance sheet items were the outputs. The findings suggest that there are no significant differences between the overall efficiency results of conventional versus Islamic banks. However, there is substantial room for improvement in cost minimization and profit maximization in both banking systems. Furthermore, the findings show no significance difference in average efficiency scores between big versus small and new versus old banks in both banking streams. This implies that size and age did not affect the performance of banks in both streams. Overall, the results are in favor of the more recent Islamic banking system.

In order to examine the efficiency in Islamic and conventional banks in the $\mathrm{GCC}^{5}$ region from 2004 to 2007, Johnes et al. (2010) used financial ratio analysis (FRA) and data envelopment analysis (DEA). In this study, Johnes et al. (2010) determined the inputs and the outputs of the Islamic banks by adopting the intermediation approach. The outputs are defined as total loans and other earning assets. Deposits and short term funding, fixed assets, general and administration expenses, and equity are defined as the inputs.

Al Khasawneh et al. (2012) examine the efficiency of Islamic banks relative to conventional banks operating in North African Arab countries, in terms of cost and revenue efficiency. This study also employs the intermediation approach to define the inputs and outputs. The inputs are personnel expenses, fixed assets, and loanable funds. Meanwhile, net loans and other earning assets are the outputs. The results indicated that Islamic banks achieved higher average revenue efficiency scores over conventional banks in this region, while the growth rate of revenue efficiency score of Islamic bank was less than conventional banks. In terms of cost efficiency, the results varied from country to another. Besides that the results also showed that both groups of banks were close to each other, with an advantage to conventional banks, which suffer less cost efficiency loss over time compared to Islamic banks.

In attempt to investigate the relative efficiency of the Islamic banking industry in the world, Kabir and Hassan (2005) employ a panel of banks during 1995-2001 by using both parametric and non-parametric techniques. In the study, intermediation approach is used to determine the inputs and outputs which the inputs are labor, fixed capital, and customer and short-term funding funds to produce outputs such as total loan, other earning assets, and off-balance sheet items. The findings show that on average, Islamic banking industry is relatively less efficient compared to their conventional counterparts in other parts of the world.

Sufian (2007) investigates the performance of Malaysian Islamic banking sector during the period of 2001-2005. Several efficiency estimates of individual banks are evaluated using nonparametric Data Envelopment Analysis (DEA). A variation of intermediation approach or asset approach is adopted to define the input and output variables of the banks. The inputs are total

${ }^{5}$ GCC stands for Gulf Cooperation Council which consists of The Kingdom of Bahrain, Kuwait, The Sultanate of Oman, Qatar, The Kingdom of Saudi Arabia, and The United Arab Emirates (UAE) 
deposits whereas the outputs are total loans (include loans to customers and other banks), investments (include investment securities held to maturity).The findings suggest that during the period of study, scale inefficiency dominates pure technical inefficiency in the Malaysian Islamic banking sector. It is found that foreign banks have exhibited higher technical efficiency compared to their domestic peers. The inclusion of risk factors has mixed impact on Malaysian Islamic banks' efficiency. The results seems to suggest that while potential economies of scale may be overestimated when risk factors are excluded, pure technical efficiency estimates on the other hand, tend to be much more sensitive to the exclusion of risk factors. The empirical results from the Spearman and Pearson tests reinforce these findings

The study of Zainal and Ismail (2012) examine the efficiency of Islamic banks in Malaysia in the year 2006 until 2010. A non-parametric based Data Envelopment Analysis (DEA) is used to estimate the efficiency using input orientation. Inputs and outputs of this study are analyzed based on intermediation approach. The inputs are total deposits, personnel expenses, and fixed assets. The outputs are total financing and advances and other earning assets. The results showed that the average TE, PTE and SE were 0.79, 0.90 and 0.88 respectively. Next, local Islamic banks scored higher TE and SE compared to foreign Islamic banks. But foreign Islamic banks scored higher PTE than that of Islamic banks.

Onour and Abdalla (2012) employ several efficiency measures and productivity changes using Data Envelopment Analysis (DEA) to investigate efficiency performance of Islamic banks in Sudan. Based on the intermediation approach the inputs are defined as salaries and wage expenses and total deposits. Meanwhile the outputs are total loans and income. The results indicate, among twelve banks included in the sample only two banks, (the largest bank in the group which is government owned, and middle sized, private bank), score technical efficiency level (i.e. scale and pure technical efficiency). In addition, the results also suggest that the smallest bank in the group (private owned), score pure technical efficiency (i.e., managerial efficiency), but scale inefficient. Furthermore, these results imply ownership is not a constraint of managerial and scale efficiency but bank's size is important factor for scale efficiency.

From the literature review, it can be concluded that past empirical studies on the relative performance of Islamic and conventional banks have used financial ratio analysis, DEA, SFA, and linear regression techniques. However, on balance, there has been relatively little use of more sophisticated techniques such as SFA and DEA, and very few studies have provided estimates of differences in productivity change between Islamic and conventional banks. From past studies, it is observed that DEA methodology has been extensively used in the Islamic Banking literature.

\section{DATA AND METHODOLOGY}

\subsection{Data}

The panel data set is extracted from consolidated income statements and balance sheets of 45 Islamic Banks in 14 countries. The annual data used in the study covers the period from 2004 to 2011. Indeed, the time span chosen was specifically chosen based on the data availability of the Islamic Banks. However, there are some banks that have just been operated since 2007 onwards such as Al Hilal Bank PJSC in UAE. The period is selected in order to provide an insight of the 
global Islamic banking performance. The list of the Islamic Banks that have been selected for this study are as shown in Table 1 below.

\section{Table 1 List of Islamic Banks by Country}

\begin{tabular}{|c|c|}
\hline Country & List of Banks \\
\hline \multirow[t]{6}{*}{ Bahrain } & AlBaraka Banking Group B.S.C \\
\hline & Arcarpita Bank B.S.C \\
\hline & Capivest \\
\hline & Khaleeji Commercial Bank \\
\hline & Kuwait Finance House \\
\hline & Venture Capital Bank \\
\hline \multirow[t]{2}{*}{ Bangladesh } & ICB Islamic Bank Ltd \\
\hline & Shahjalal Islami Bank Ltd \\
\hline \multirow[t]{5}{*}{ Iran } & Bank Saderat Iran \\
\hline & Bank Sarmaye \\
\hline & Bank Tejarat \\
\hline & Kafarin Bank \\
\hline & Parsian \\
\hline \multirow[t]{2}{*}{ Jordan } & Jordan Dubai Islamic Bank \\
\hline & Jordan Islamic Bank \\
\hline \multirow[t]{2}{*}{ Kuwait } & Kuwait Finance House \\
\hline & Kuwait International Bank \\
\hline Lebanon & Arab Finance House (SAL) \\
\hline \multirow{7}{*}{ Malaysia } & Alliance Islamic Bank Berhad \\
\hline & AmIslamic Bank Berhad \\
\hline & Bank Islam Malaysia Berhad \\
\hline & CIMB Islamic Bank Berhad \\
\hline & Kuwait Finance House (Malaysia) Berhad \\
\hline & OCBC AlAmin \\
\hline & RHB Islamic Bank \\
\hline \multirow[t]{5}{*}{ Pakistan } & AlBaraka Bank (Pakistan) Limited \\
\hline & Burj Bank Limited \\
\hline & Dubai Islamic Pakistan Limited \\
\hline & First National Bank Modaraba \\
\hline & Meezan Bank Limited \\
\hline \multirow[t]{3}{*}{ Qatar } & Masraf Al Rayan \\
\hline & Qatar International Islamic Bank \\
\hline & Qatar Islamic Bank \\
\hline Saudi Arabia & Al Rajhi Bank \& Investment Corporation \\
\hline Tunisia & AlBaraka Bank Tunisia \\
\hline \multirow[t]{2}{*}{ Turkey } & $\begin{array}{l}\text { Kuveyt Turk Katilim A.S. - Kuwait Turkish } \\
\text { Participation Bank Inc }\end{array}$ \\
\hline & Asya Katilim Bankasi AS- Bank Asya \\
\hline
\end{tabular}




\begin{tabular}{|l|l|} 
& Turkiye Finans Katilim Bankasi AS \\
& Abu Dhabi Islamic Bank \\
\hline \multirow{5}{*}{ UAE } & \\
\hline \multirow{5}{*}{ Yemen } & Al Hilal Bank PJSC \\
\hline & Dubai Finance PJSC \\
\hline & Sharjah Islamic Bank PLC \\
\hline & Tamweel PJSC \\
\hline & Shamil Bank of Yemen \& Bahrain \\
\hline
\end{tabular}

\subsection{Input and Output Variables}

The definition of inputs and outputs in measuring efficiency remains the debatable issues as discussed extensively in Humprey (1985). However, the intermediation approach is seen as the most consistent with the concept of Islamic banking. This study is focusing on bank's role in intermediating savers and investors of fund. For that reason, in attempt to evaluate the efficiency of banks overall, this study employs the intermediation approach like many existing studies on banking efficiency such as Sufian, Mohamad, and Abdul Majid (2008), Johnes, Izzeldin, and Pappas (2010), Mohammad (2010), and Bambang (2011). Following Dar and Presley (2000), Yudistra (2003) explains that the reason for choosing the intermediation approach is because of the main character of Islamic banks, which is often claimed as a joint stock firms which shares are easily tradable.

Following the input and output by Isik and Hassan (2002); Hassan (2006), and Shamsher et al. (2008), the input variables chosen in this study are personnel expenses, fixed assets, deposits and short term funding (deposits) whereas the output variables are represented by total loans and total securities. Meanwhile other explanatory variables are such as Total Assets, Interest Income, Interest Expenses, Non-interest income, non-interest expenses, and ownership.

\section{METHODOLOGY}

Pertaining to the aims of this study to measure the cost efficiency of the global Islamic banking sector, therefore Data Envelopment Analysis (DEA) has been adopted. Apart from that, the sources of technical efficiency, namely pure technical efficiency and scale efficiency are also determined. Two models, namely the DEA constant returns to scale and variable returns to scale models are employed. First, this study assumes that there are $n$ DMUs to be evaluated with varying amounts of $K$ different inputs to produce $M$ different outputs. Both DEA models seek to determine which of the $n$ DMUs will establish an envelopment surface. This model assumes a constant return to scale mode of operation. It measures efficiency in terms of overall technical efficiency. The DEA efficiency score is obtained by taking the maximum ratio of weighted outputs to weighted inputs. This measurement allows multiple outputs and inputs to be reduced to single 'virtual' input $(x i)$ and single 'virtual' output ( $y i)$ by optimal weights.

$$
\operatorname{Max}_{u, v}\left(u^{\prime} y_{i} i / v^{\prime} x_{i}\right)
$$


$\begin{array}{ll}\text { s.t. } & \mathrm{u}^{\prime} \mathrm{y}_{\mathrm{j}} / \mathrm{x}_{\mathrm{j}} \\ \mathrm{u}, v & \leq 1\end{array}$

$\mathrm{j}=1,2, \ldots, \mathrm{N}$

The vectors $x i$ and $y i$ indicate the $K \times N$ input matrix and $K \times M$ output matrix for $i$ th DMUs respectively. The $K \times N$ input matrix, $X$, and the $K \times M$ output matrix, $Y$, represent the data for all $N$ DMUs. The efficiency for the $i$ th DMU is maximized by finding values for $u$ and $v$, to avoid the problem of an infinite number of solutions, a constant constraint $\left(\square^{\prime} x i=1\right)$ is imposed on the equation (1).

$$
\begin{array}{ll}
\operatorname{Max},\left(\mu^{\prime} \mathrm{yi}\right), & \\
\text { s.t. } \quad p^{\prime} \mathrm{x}_{\mathrm{i}} & =1 \\
\mu \mathrm{y}_{\mathrm{j}}-p^{\prime} \mathrm{x}_{\mathrm{j}} & \leq 0, \\
\mu, p, & \geq 0,
\end{array}
$$

The notations $\mu$ and $p$ indicate the transformation of $u$ and $v$. The envelopment form of the linear programming problem is shown below:

$$
\begin{array}{llll}
\operatorname{Min}_{\theta, \lambda} & & \theta, \\
\text { s.t. } & \mathrm{yi}+\mathrm{Y} \lambda & \geq & 0, \\
& \theta \mathrm{x}_{\mathrm{i}}-\mathrm{X} \lambda & \geq & 0, \\
& \lambda & \geq & 0,
\end{array}
$$

Where $\theta$ is a scalar and $\lambda$ is an $N \times 1$ vector of constants. The value of $\theta$ is the efficiency score for the $i$ th DMU; it should be solved $N$ times, one for each DMU.

To account for the variable returns to scale assumption, the convexity constraint, $N 1^{\prime} \lambda=1$, is applied to Equation (2).

$\min _{\theta, \lambda}$

$$
\begin{array}{lll}
\theta, & & \\
& \text { s.t. } & -\mathrm{yi}+\mathrm{Y} \lambda \geq 0, \\
& & \theta \mathrm{x}_{\mathrm{i}}-\mathrm{X} \lambda \geq 0, \\
\mathrm{~N} 1^{\prime} \lambda=1 & \\
\lambda \quad \geq 0, &
\end{array}
$$

Where the elements in the vector $\theta$ are less than or equal to 1 , and $N 1^{\prime} \lambda$ is an $N \times 1$ vector of ones.

To account for allocative efficiency, the vector of input prices wi is inserted in Equation (4), shown as follows:

$$
\begin{aligned}
& \operatorname{Min} \lambda, \mathrm{xi}^{*} \mathrm{~W}_{\mathrm{i}} \mathrm{X}_{\mathrm{i}}{ }^{*} \text {, } \\
& \text { s.t. }-y_{i}+Y \lambda \geq 0 \text {, } \\
& \mathrm{x}_{\mathrm{i}}^{*}-\mathrm{X} \lambda \geq 0 \text {, } \\
& \mathrm{N} 1{ }^{\prime} \lambda=1 \text {, } \\
& \lambda \geq 0 \text {, }
\end{aligned}
$$

Where $\mathrm{x}$ " $\mathrm{i}$ is the cost minimizing vector of input quantities for the $i$ th DMU, given the input prices $w i$ and the output levels $y i$. The total cost efficiency or overall efficiency of the $i$ th DMU is calculated as:

$$
C E=\frac{w_{i} x_{i}}{w_{i} x_{i}}
$$




\section{EMPIRICAL RESULTS AND DISCUSSION}

\subsection{The Overall Efficiency Performance of Islamic Banks (2004-2011)}

Figure 1 presents the means of the efficiency scores for the years 2004 until 2011 of 44 Islamic banks operating in 14 selected countries in the world. Based on the constructed frontiers, Islamic banks in the world exhibited a mean overall efficiency of 0.2846 in 2004 and increases to 0.3630 in 2005. However, the Islamic banks in the world show consistent declining overall technical efficiency in 2006 that is from 0.3556 to 0.3118 in 2010, and the lowest is in 2011 with only 0.2434 . Based on Table 3 and Figure 1, it is seen that pure technical efficiency is indeed higher than technical efficiency and scale efficiency. In 2004, all Islamic banks stated pure technical efficiency of 0.5511 and shows major increases in 2005 that is 0.7120 . The scores continue to increase in 2006 with 0.7537 but begin to decline to 0.7403 in 2007. As shown in Figure 1, it appears that for each year, pure technical efficiency is higher than scale efficiency. This indicates that the Islamic banks inefficiency is mainly attributed to scale efficiency rather than pure technical efficiency.

Figure 1 Efficiency Performance of Global Islamic Banking (2004-2011)

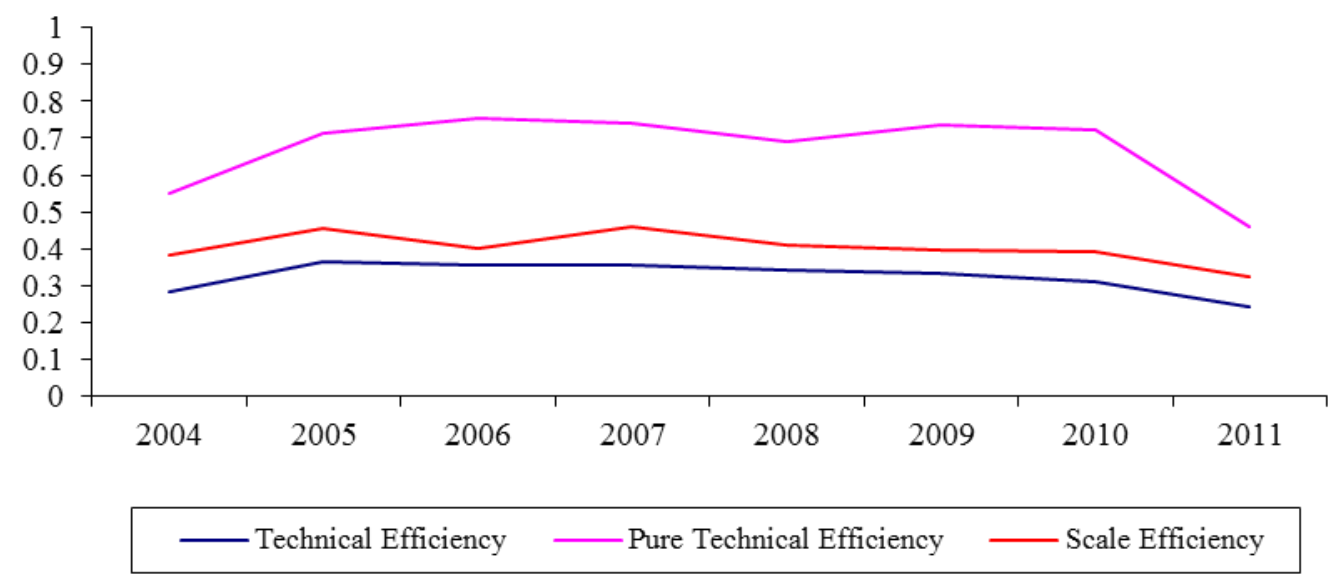

\subsection{The Technical Efficiency Performance of Islamic Banks}

According to Table 2 , with respect to technical efficiency scores, the Islamic banks in Malaysia have the highest technical efficiency scores with mean efficiency of 0.5538 from 2004 to 2011. In 2005, the technical efficiency scores of the Islamic banks in Malaysia is 0.4890. The technical efficiency decreases to 0.4580 in 2006 and starts to improve in 2007 at 0.5121 . The improvement continues in 2008 to 0.6409 but decreases to 0.5382 in 2009 . However, the technical efficiency of Islamic banks in Malaysia increases in 2010 and 2011 with 0.5498 and 0.5567 respectively.

Following Malaysia, the Islamic banks in Tunisia have the second highest average technical efficiency scores out of 14 examined countries with mean efficiency of 0.5460. In 2004, the technical efficiency score is 0.6169 and decreases to 0.6108 in 2005 . The declining rate continues to 0.4750 in 2006. However, the Islamic banks in Tunisia manage to recover in terms of their technical efficiency in 2007 with mean scores of 0.5277. In 2008, the technical efficiency scores decreases to 
0.5200 but increases in 2009 to 0.5253 . In 2010, the Islamic banks in Tunisia appear to improve their technical efficiency scores to 0.5465 .

With the average technical efficiency scores of 0.5171 , the Islamic banks in Bahrain appear to be the third highest technical efficiency following Tunisia. From 2004 to 2006, the Islamic banks in Bahrain shows gradual increase in technical efficiency scores which is 0.2055 in 2004, 0.4960 in 2005, and 0.6170 in 2006. However, since 2007, the trend declines until 2011. In 2007, the technical efficiency scores drop to 0.4423 as compared to 0.6170 in 2006 . Furthermore, in 2008 the technical efficiency decreases to $0.3823,0.3777$ in 2010 , and 0.3719 in 2011.

By referring to result exhibited as in Table 2, it appears that the Islamic banks in UAE have the lowest technical efficiency score. The average technical efficiency scores of the Islamic banks in UAE from 2004 to 2011 is 0.2299 . In 2004, the Islamic banks in UAE have average technical efficiency score of 0.3421 and continues to decrease since 2005. In 2005, the technical efficiency decreases to 0.3398 as compared to 0.3421 in previous year. In 2006, the technical efficiency of the Islamic banks in UAE further decreases to 0.3113. The technical efficiency score of the Islamic banks in the UAE started to improved again in 2009 with average score of 0.2921 but fall to 0.2862 in 2010. In 2011, the technical efficiency of the Islamic banks decreases to 0.2598.

$\underline{\text { Table } 2 \text { Technical Efficiency Scores of Islamic Banks by Country (2004-2011) }}$

\begin{tabular}{l|lllllllll}
\hline $\begin{array}{l}\text { Country/ } \\
\text { Efficiency } \\
\text { Scores }\end{array}$ & $\mathbf{2 0 0 4}$ & $\mathbf{2 0 0 5}$ & $\mathbf{2 0 0 6}$ & $\mathbf{2 0 0 7}$ & $\mathbf{2 0 0 8}$ & $\mathbf{2 0 0 9}$ & $\mathbf{2 0 1 0}$ & $\mathbf{2 0 1 1}$ & Mean \\
\hline Bahrain & 0.4055 & 0.4960 & 0.6170 & 0.4423 & 0.4268 & 0.3823 & 0.3777 & 0.3719 & $\mathbf{0 . 5 1 7 1}$ \\
Bangladesh & 0.3081 & 0.3137 & 0.3192 & 0.2396 & 0.2647 & 0.2434 & 0.1084 & 0.2222 & $\mathbf{0 . 2 4 7 0}$ \\
Iran & 0.1424 & 0.2761 & 0.2639 & 0.2421 & 0.2326 & 0.2363 & 0.2468 & 0.2474 & $\mathbf{0 . 2 4 9 8}$ \\
Jordan & 0.6715 & 0.5400 & 0.5453 & 0.5629 & 0.4038 & 0.4606 & 0.3225 & 0.2829 & $\mathbf{0 . 4 7 3 7}$ \\
Kuwait & 0.3709 & 0.3437 & 0.3218 & 0.3259 & 0.3153 & 0.3186 & 0.3216 & 0.3183 & $\mathbf{0 . 3 2 9 5}$ \\
Lebanon & 0.0000 & 0.0000 & 0.0000 & 0.2599 & 0.2537 & 0.2455 & 0.2334 & 0.0000 & $\mathbf{0 . 2 4 8 1}$ \\
Malaysia & 0.0000 & 0.4890 & 0.4580 & 0.5121 & 0.6409 & 0.5382 & 0.5498 & 0.5567 & $\mathbf{0 . 5 5 3 8}$ \\
Pakistan & 0.2841 & 0.5963 & 0.5008 & 0.4486 & 0.3692 & 0.2918 & 0.3015 & 0.3108 & $\mathbf{0 . 3 5 7 4}$ \\
Qatar & 0.3470 & 0.3459 & 0.3704 & 0.3661 & 0.2941 & 0.3025 & 0.3053 & 0.3283 & $\boldsymbol{0 . 3 3 2 4}$ \\
Saudi & 0.1866 & 0.2118 & 0.2562 & 0.2457 & 0.2584 & 0.2584 & 0.2579 & 0.2747 & $\mathbf{0 . 2 4 3 7}$ \\
Tunisia & 0.6169 & 0.6108 & 0.4750 & 0.5277 & 0.5200 & 0.5253 & 0.5465 & 0.0000 & $\mathbf{0 . 5 4 6 0}$ \\
Turkey & 0.0000 & 0.2262 & 0.2258 & 0.2280 & 0.2329 & 0.2377 & 0.2380 & 0.2347 & $\mathbf{0 . 2 3 6 0}$ \\
UAE & 0.3421 & 0.3398 & 0.3113 & 0.2863 & 0.2837 & 0.2921 & 0.2862 & 0.2598 & $\mathbf{0 . 2 2 9 9}$ \\
Yemen & 0.3092 & 0.2931 & 0.3135 & 0.2637 & 0.2788 & 0.2989 & 0.2699 & 0.0000 & $\mathbf{0 . 2 5 3 4}$ \\
\hline
\end{tabular}

\section{The Pure Technical Efficiency Scores of Global Islamic Banks (2004-2011)}

Based on the result obtained by using DEA approach, Table 3 has been constructed to show the average pure technical efficiency scores of the 44 banks that have been measured in 14 countries for this study. In order to show the trend of the efficiency in each country, the result is then being presented in graph as in Figure 3(a) to 3(n) below. 
Table 3 Average Pure Technical Efficiency Scores of Global Islamic banks (2004-2011)

\begin{tabular}{|c|c|c|c|c|c|c|c|c|c|}
\hline $\begin{array}{l}\text { Country/ } \\
\text { Efficiency } \\
\text { Scores }\end{array}$ & 2004 & 2005 & 2006 & 2007 & 2008 & 2009 & 2010 & 2011 & Mean \\
\hline Bahrain & 0.6585 & 0.5746 & 0.6685 & 0.6046 & 0.5424 & 0.5134 & 0.5122 & 0.5347 & 0.7519 \\
\hline Bangladesh & 0.7608 & 0.7638 & 0.8095 & 0.5893 & 0.3616 & 0.7319 & 0.6641 & 0.2222 & 0.6802 \\
\hline Iran & 0.4999 & 0.9427 & 0.9557 & 0.8914 & 0.7834 & 0.7762 & 0.8380 & 0.8259 & 0.8285 \\
\hline Jordan & 0.8181 & 0.7205 & 0.7277 & 0.7237 & 0.6528 & 0.7800 & 0.5497 & 0.4620 & 0.8668 \\
\hline Kuwait & 0.8061 & 0.7993 & 0.7874 & 0.8272 & 0.7948 & 0.8190 & 0.8389 & 0.3182 & 0.8126 \\
\hline Lebanon & 0.0000 & 0.0000 & 0.0000 & 0.2599 & 0.2594 & 0.2633 & 0.2689 & 0.0000 & 0.9446 \\
\hline Malaysia & 0.0000 & 0.7466 & 0.8669 & 0.8419 & 0.8743 & 0.8156 & 0.8172 & 0.8593 & 0.8192 \\
\hline Pakistan & 0.3588 & 0.6517 & 0.5539 & 0.4866 & 0.4268 & 0.3358 & 0.3430 & 0.3493 & 0.6793 \\
\hline Qatar & 0.8938 & 0.8528 & 0.9536 & 0.9411 & 0.8791 & 0.9000 & 0.9575 & 1.0000 & 0.9222 \\
\hline Saudi & 0.4983 & 0.5889 & 0.8680 & 0.8325 & 0.9311 & 0.9311 & 0.9256 & 0.2747 & 0.8163 \\
\hline Tunisia & 0.8399 & 0.8286 & 0.7230 & 0.8670 & 0.8460 & 0.9461 & 1.0000 & 0.0000 & 0.8644 \\
\hline Turkey & 0.0000 & 0.9452 & 0.9525 & 0.9751 & 0.8159 & 0.8153 & 0.8474 & 0.8562 & 0.8327 \\
\hline UAE & 0.7616 & 0.7770 & 0.7904 & 0.7516 & 0.7313 & 0.7508 & 0.7347 & 0.7224 & 0.7248 \\
\hline Yemen & 0.8194 & 0.7764 & 0.8949 & 0.7726 & 0.7562 & 0.9253 & 0.8193 & 0.0000 & 0.8234 \\
\hline
\end{tabular}

Table 3 shows the average pure technical efficiency of the Islamic banks by country from 2004 to 2011. Based on the table, it is clearly seen that Islamic banks in Lebanon has the highest pure technical efficiency among 14 examined countries. It stated 0.9446 or $94.46 \%$ pure technical efficiency. However, the Islamic banks in Lebanon only been operating from 2007 until 2010 as compared to other Islamic banks in other examined countries. With the pure technical efficiency scores of 0.9222, the Islamic banks in Qatar came second most efficiency following Lebanon. Although it is seen that the efficiency scores increase and decrease from 2004-2011, but the two Islamic banks in Qatar managed to maintain high pure technical efficiency score consistently and has experienced 100\% pure technical efficiency in 2011 which indicates that the Islamic banks in Qatar has fully utilized the amount of inputs to turn into the outputs without any wastage at this year. It shows that these banks are very well-managed as compared other Islamic banks in other examined countries.

The Islamic banks in Jordan have the third highest pure technical efficiency from 2004 until 2011. It stated 0.8668 efficiency scores. In 2004, the efficiency of the Islamic banks in Jordan is very high which is at 0.8181 indicating of about only 0.1819 waste of inputs of that particular year. The efficiency scores however portray a gradual loss since 2005 until 2011. In 2005, the efficiency score starts to decrease to 0.7205 as compared to 0.8181 in 2004. The declination continues until 2008 which stated only 0.6528 which implies that the Islamic banks in Jordan have a waste of 0.3472 inputs in converting them to outputs. Nevertheless, in 2009 the efficiency scores have improved to 0.7800 but continue to decrease again in 2010 to 0.5497 . In 2011, the Islamic bank in Jordan is the most inefficient by having only 0.4620 pure technical efficiency which is about 0.5380 wastes of resources.

Referring to Table 3 it appears that among the 14 countries, the Islamic banks in Bangladesh and Pakistan are the least efficient in terms of technical efficiency. The Islamic banks in Bangladesh recorded the average pure technical efficiency of 0.6802 meanwhile Pakistan's average pure technical efficiency of 0.6793. In the beginning of the examined years, Bangladesh shows high efficiency scores but after that started to show decreasing rate in 2007. As compared to Pakistan, Bangladesh is more consistent on being technically efficient. This is proven by looking at Table 5; 
Islamic banks in Pakistan have consistently recorded low average pure technical efficiency scores throughout the years.

\subsection{The Scale Efficiency Performance of Islamic banks by country (2004-2011)}

Table 4 presents the average scale efficiency scores of Islamic banks by country from 2004 until 2011. Referring to Figure shown below, with respect to scale efficiency, it is clearly seen that among 14 countries that are being investigated, the Islamic banks in Jordan, Tunisia, Malaysia, and Bahrain have the highest average scale efficiency scores from 2004 to 2011. Based on Table 4, Jordan is seen to have the highest average scale efficiency scores that is 0.6757 . In 2004, the Islamic banks in Jordan stated 0.7695 scale efficiency and the number dropped to 0.7458 in 2005 . Scale efficiency scores of the Islamic banks in Jordan continues to drop to as low as 0.4746 in 2006. However, in 2007 managed to recover its scale efficiency to 0.6111. In 2009, the Islamic banks in Jordan show a declining rate to 0.5699 and 0.4606 in 2010. In 2011, the scale efficiency scores slightly improved to 0.6469 .

Table 4 Average Scale Efficiency Scores of Islamic banks by Country (2004-2011)

\begin{tabular}{|c|c|c|c|c|c|c|c|c|c|}
\hline $\begin{array}{l}\text { Country/ Scale } \\
\text { Efficiency }\end{array}$ & 2004 & 2005 & 2006 & 2007 & 2008 & 2009 & 2010 & 2011 & Mean \\
\hline Bahrain & 0.6585 & 0.5746 & 0.6685 & 0.6046 & 0.5424 & 0.5134 & 0.5122 & 0.5347 & 0.5732 \\
\hline Bangladesh & 0.4049 & 0.4106 & 0.3943 & 0.4222 & 0.1688 & 0.3329 & 0.3355 & 0.3418 & 0.3677 \\
\hline Iran & 0.3336 & 0.2927 & 0.2762 & 0.6402 & 0.2982 & 0.3083 & 0.2955 & 0.3037 & 0.3045 \\
\hline Jordan & 0.7695 & 0.7458 & 0.4746 & 0.7456 & 0.6111 & 0.5699 & 0.4606 & 0.6459 & 0.6757 \\
\hline Kuwait & 0.4646 & 0.4333 & 0.4082 & 0.3954 & 0.4009 & 0.3906 & 0.3818 & 0.3858 & 0.4076 \\
\hline Lebanon & 0.0000 & 0.0000 & 0.0000 & 0.2599 & 0.2594 & 0.2633 & 0.2689 & 0.0000 & 0.2629 \\
\hline Malaysia & 0.0000 & 0.7178 & 0.5290 & 0.5932 & 0.7098 & 0.6586 & 0.6749 & 0.6437 & 0.6511 \\
\hline Pakistan & 0.3588 & 0.6517 & 0.5539 & 0.4866 & 0.4268 & 0.3358 & 0.3430 & 0.3493 & 0.4049 \\
\hline Qatar & 0.3881 & 0.4052 & 0.3872 & 0.3883 & 0.3344 & 0.3361 & 0.3191 & 0.3283 & 0.3608 \\
\hline Saudi & 0.3744 & 0.3597 & 0.2952 & 0.2951 & 0.2776 & 0.2776 & 0.2786 & 0.2878 & 0.2058 \\
\hline Tunisia & 0.7344 & 0.7371 & 0.6569 & 0.6087 & 0.6146 & 0.5552 & 0.5465 & 0.0000 & 0.6362 \\
\hline Turkey & 0.0000 & 0.2393 & 0.2370 & 0.2339 & 0.3055 & 0.2993 & 0.2993 & 0.2990 & 0.3045 \\
\hline UAE & 0.4580 & 0.4410 & 0.4019 & 0.3996 & 0.3952 & 0.4056 & 0.4069 & 0.3749 & 0.3963 \\
\hline Yemen & 0.3773 & 0.3775 & 0.3503 & 0.3413 & 0.3688 & 0.3230 & 0.3295 & 0.0000 & 0.3525 \\
\hline
\end{tabular}

As for Malaysia, the Islamic banks started to operate in 2005 and made Malaysia appear to be the second highest scale efficiency scores following Jordan. In 2005, the scale efficiency of all Islamic banks in Malaysia is 0.7178 and decreases to 0.5290 in 2006. The banks shows improvement in scale efficiency in 2007 and scores 0.5932 . The improvement in scale efficiency continues in 2008 with 0.7098 . In 2009 , the scale efficiency score decreases to 0.6585 but later improved to 0.6749 in 2010. In 2011, the Islamic banks in Malaysia once again experiencing decreasing scale efficiency to 0.6437 .

The result in Table 4 reveals that Islamic banks in Tunisia have the third highest average scale efficiency scores following Malaysia. It has recorded a mean scale efficiency of 0.6362 . The Islamic banks in Tunisia demonstrated a declining trend in scale efficiency since 2006. In 2004, the average scale efficiency scores of Islamic banks in Tunisia is 0.7344 and 0.7371 the following year. 
In 2006, the scale efficiency scores started to decrease to 0.6569. The efficiency keeps on decreasing in 2007 with 0.6087 . The scale efficiency scores exhibits a slight increase to 0.6146 in 2009 but begin to fall to 0.5552 in 2009 and further decrease to 0.5465 in 2010 .

The least efficient with respect to scale efficiency are the Islamic banks in Saudi. From the result in Table 4, it is found that the Islamic banks have the average scale efficiency score as low as 0.2058. Based on Table 4, the result shows that the Islamic banks in Saudi have consistently low in scale efficiency scores as compared to other banks in other examine countries. From 2004 until 2009, the scale efficiency is in declining trend of which in 2004 the scale efficiency is 0.3744 , in 2005 is 0.3597, 0.2952 in 2006, 0.2951 in 2007, 0.2776 in 2008 and 2009. In 2010, the scale efficiency has slightly improved to 0.2786 and begins to decrease again to 0.2878 in 2011 .

$\underline{\text { Table } 5 \text { Evaluating Islamic Banks Efficiency Performance by Country (2004-2011) }}$

\begin{tabular}{|c|c|c|c|c|c|c|}
\hline \multirow[t]{2}{*}{ Country } & \multicolumn{2}{|c|}{ TE } & \multicolumn{2}{|l|}{ PTE } & \multicolumn{2}{|l|}{ SE } \\
\hline & $\begin{array}{l}\text { The Best } \\
\text { Bank }\end{array}$ & The worst Bank & $\begin{array}{l}\text { The Best } \\
\text { Bank }\end{array}$ & $\begin{array}{l}\text { The Worst } \\
\text { Bank }\end{array}$ & $\begin{array}{l}\text { The Best } \\
\text { Bank }\end{array}$ & $\begin{array}{l}\text { The Worst } \\
\text { Bank }\end{array}$ \\
\hline Bahrain & $\begin{array}{l}\text { Venture Capital } \\
\text { Bank } \\
(0.9479)\end{array}$ & $\begin{array}{l}\text { Al Baraka } \\
\text { Banking Group } \\
\text { B.S.C } \\
(0.2776)\end{array}$ & $\begin{array}{l}\text { Khaleeji Commercial } \\
\text { Bank } \\
(0.8708)\end{array}$ & $\begin{array}{l}\text { Venture } \\
\text { Capital Bank } \\
(0.6435)\end{array}$ & $\begin{array}{l}\text { Capivest } \\
(0.7559)\end{array}$ & $\begin{array}{l}\text { Al Baraka } \\
\text { Banking } \\
\text { Group } \\
\text { B.S.C } \\
(0.3649)\end{array}$ \\
\hline $\begin{array}{l}\text { Banglades } \\
\text { h }\end{array}$ & $\begin{array}{l}\text { Shahjalal Islami } \\
\text { Bank Ltd } \\
(0.2848)\end{array}$ & $\begin{array}{l}\text { ICB Islamic } \\
\text { Bank Ltd } \\
(0.2093)\end{array}$ & $\begin{array}{l}\text { Shahjalal Islami } \\
\text { Bank Ltd } \\
(0.7814)\end{array}$ & $\begin{array}{l}\text { ICB Islamic } \\
\text { Bank Ltd } \\
(0.5789)\end{array}$ & $\begin{array}{l}\text { ICB Islamic Bank } \\
\text { Ltd } \\
(0.3713)\end{array}$ & $\begin{array}{l}\text { Shahjalal } \\
\text { Islami Bank } \\
\text { Ltd } \\
(0.3641)\end{array}$ \\
\hline Iran & $\begin{array}{l}\text { Parsian Bank } \\
(0.2658)\end{array}$ & $\begin{array}{l}\text { Bank Saderat } \\
\text { Iran } \\
(0.2293)\end{array}$ & $\begin{array}{l}\text { Bank Tejarat } \\
(0.8890)\end{array}$ & $\begin{array}{l}\text { Bank } \\
\text { Sarmaye } \\
(0.7091)\end{array}$ & $\begin{array}{l}\text { Bank Sarmaye } \\
(0.3594)\end{array}$ & $\begin{array}{l}\text { Bank } \\
\text { Saderat } \\
(0.26442)\end{array}$ \\
\hline Jordan & $\begin{array}{l}\text { Jordan Dubai } \\
\text { Islamic Bank } \\
(0.6414)\end{array}$ & $\begin{array}{l}\text { Jordan Islamic } \\
\text { Bank } \\
(0.3059)\end{array}$ & $\begin{array}{l}\text { Jordan Dubai Islamic } \\
\text { Bank } \\
(0.7427)\end{array}$ & $\begin{array}{l}\text { Jordan } \\
\text { Islamic Bank } \\
(0.6159)\end{array}$ & $\begin{array}{l}\text { Jordan Dubai } \\
\text { Islamic Bank } \\
(0.8557)\end{array}$ & $\begin{array}{l}\text { Jordan } \\
\text { Islamic } \\
\text { Bank } \\
(0.4958)\end{array}$ \\
\hline Kuwait & $\begin{array}{l}\text { Kuwait } \\
\text { International } \\
\text { Bank } \\
(0.3829)\end{array}$ & $\begin{array}{l}\text { Kuwait Finance } \\
\text { House } \\
(0.2761)\end{array}$ & $\begin{array}{l}\text { Kuwait Finance } \\
\text { House } \\
(0.8309)\end{array}$ & $\begin{array}{l}\text { Kuwait } \\
\text { International } \\
\text { Bank } \\
(0.7943)\end{array}$ & $\begin{array}{l}\text { Kuwait } \\
\text { International Bank } \\
(0.4829)\end{array}$ & $\begin{array}{l}\text { Kuwait } \\
\text { Finance } \\
\text { House } \\
(0.3322)\end{array}$ \\
\hline Lebanon & $\begin{array}{l}\text { Arab Finance } \\
\text { House } \\
(0.2481)\end{array}$ & - & $\begin{array}{l}\text { Arab Finance House } \\
(0.9446)\end{array}$ & - & $\begin{array}{l}\text { Arab } \\
\text { House } \\
(0.2629)\end{array}$ & - \\
\hline Malaysia & $\begin{array}{l}\text { AmIslamic Bank } \\
\text { Berhad } \\
(0.8363)\end{array}$ & $\begin{array}{l}\text { Bank Islam } \\
\text { Malaysia Berhad } \\
(0.3381)\end{array}$ & $\begin{array}{l}\text { AmIslamic Bank } \\
\text { Berhad } \\
(1.0000)\end{array}$ & $\begin{array}{l}\text { Alliance } \\
\text { Islamic Bank } \\
\text { Berhad } \\
(0.6687)\end{array}$ & $\begin{array}{l}\text { AmIslamic Bank } \\
\text { Berhad } \\
(0.8363)\end{array}$ & $\begin{array}{l}\text { Bank Islam } \\
\text { Malaysia } \\
\text { Berhad } \\
(0.3982)\end{array}$ \\
\hline
\end{tabular}




\begin{tabular}{|c|c|c|c|c|c|c|}
\hline Pakistan & $\begin{array}{l}\text { First National } \\
\text { Bank Modaraba } \\
(0.6999)\end{array}$ & $\begin{array}{l}\text { Dubai Islamic } \\
\text { Pakistan Limited } \\
(0.2512)\end{array}$ & $\begin{array}{l}\text { First National Bank } \\
\text { Modaraba } \\
(0.9102)\end{array}$ & $\begin{array}{l}\text { Dubai Islamic } \\
\text { Pakistan } \\
\text { Limited } \\
\\
(0.7823)\end{array}$ & $\begin{array}{l}\text { First National Bank } \\
\text { Modaraba } \\
(0.7480)\end{array}$ & $\begin{array}{l}\text { Al Baraka } \\
\text { Bank } \\
\text { (Pakistan) } \\
\text { Limited } \\
(0.3095)\end{array}$ \\
\hline Qatar & $\begin{array}{l}\text { Qatar } \\
\text { International } \\
\text { Islamic Bank } \\
(0.3485)\end{array}$ & $\begin{array}{l}\text { Qatar Islamic } \\
\text { Bank } \\
\\
(0.3163)\end{array}$ & $\begin{array}{l}\text { Qatar International } \\
\text { Islamic Bank } \\
(0.9409)\end{array}$ & $\begin{array}{l}\text { Qatar Islamic } \\
\text { Bank } \\
(0.9035)\end{array}$ & $\begin{array}{l}\text { Qatar International } \\
\text { Islamic Bank } \\
\text { (0.3699) }\end{array}$ & $\begin{array}{l}\text { Qatar } \\
\text { Islamic } \\
\text { Bank } \\
(0.3518)\end{array}$ \\
\hline Saudi & $\begin{array}{l}\text { Al Rajhi Bank } \\
\text { and Investment } \\
\text { Corporation } \\
(0.2437)\end{array}$ & - & $\begin{array}{l}\text { Al Rajhi Bank and } \\
\text { Investment } \\
\text { Corporation } \\
(0.8163)\end{array}$ & - & $\begin{array}{l}\text { Al Rajhi Bank and } \\
\text { Investment } \\
\text { Corporation } \\
(0.3058)\end{array}$ & - \\
\hline Tunisia & $\begin{array}{l}\text { Al Baraka Bank } \\
\text { Tunisia } \\
(0.5460)\end{array}$ & - & $\begin{array}{l}\text { Al Baraka Bank } \\
\text { Tunisia } \\
(0.8644)\end{array}$ & - & $\begin{array}{l}\text { Al Baraka Bank } \\
\text { Tunisia } \\
(0.6362)\end{array}$ & - \\
\hline Turkey & $\begin{array}{l}\text { Turkiye Finans } \\
\text { Katilim Bankasi } \\
\text { AS } \\
(0.2586)\end{array}$ & $\begin{array}{l}\text { Asya Katilim } \\
\text { Bankasi AS } \\
(0.2209)\end{array}$ & $\begin{array}{l}\text { Kuveyt Turk Katilim } \\
\text { Bankasi A.S. } \\
(0.9724)\end{array}$ & $\begin{array}{l}\text { Turkiye } \\
\text { Finans } \\
\text { Katilim } \\
\text { Bankasi AS } \\
(0.5827)\end{array}$ & $\begin{array}{l}\text { Turkiye Finans } \\
\text { Katilim Bankasi } \\
\text { AS } \\
(0.4439)\end{array}$ & $\begin{array}{l}\text { Asya } \\
\text { Katilim } \\
\text { Bankasi AS } \\
\\
(0.2346)\end{array}$ \\
\hline UAE & $\begin{array}{ll}\text { Amlak } & \text { Finance } \\
\text { PJSC } & \\
(0.3824) & \end{array}$ & $\begin{array}{l}\text { Al Hilal Bank } \\
\text { PJSC } \\
(0.2186)\end{array}$ & $\begin{array}{l}\text { Dubai Islamic Bank } \\
\text { PLC } \\
(0.8854)\end{array}$ & $\begin{array}{l}\text { Tamweel } \\
\text { PJSC } \\
(0.5562)\end{array}$ & $\begin{array}{ll}\text { Amlak } & \text { Finance } \\
\text { PJSC } & \\
(0.5325) & \end{array}$ & $\begin{array}{l}\text { Al Hilal } \\
\text { Bank PJSC } \\
(0.2671)\end{array}$ \\
\hline Yemen & $\begin{array}{l}\text { Shamil Bank of } \\
\text { Yemen and } \\
\text { Bahrain } \\
(0.2534)\end{array}$ & - & $\begin{array}{l}\text { Shamil Bank of } \\
\text { Yemen and Bahrain } \\
(0.8234)\end{array}$ & - & $\begin{array}{l}\text { Shamil Bank of } \\
\text { Yemen and } \\
\text { Bahrain } \\
(0.3525)\end{array}$ & - \\
\hline
\end{tabular}

Table 5 presents the summary of efficiency by denoting the best bank and the worst bank of each country in terms of technical efficiency, pure technical efficiency and scale efficiency. In Bahrain, it is seen that Venture Capital Bank is the best performer in terms of technical efficiency that is 0.9479 but has performed the worst in terms of pure technical efficiency that is only 0.6435 as compared to Khaleeji Commercial Bank which appears as the more efficient in terms of pure technical efficiency with the score of 0.8708. In terms of scale efficiency, it is seen that Capivest is the most efficient by scoring 0.7559. Apparently, as seen in Table 5, Al Baraka Banking Group B.S.C is the worst performer in terms of technical efficiency as well as scale efficiency by scoring 0.2776 and 0.3649 respectively. This indicates that, among six banks being examined in Bahrain, $\mathrm{Al}$ Baraka Banking Group B.S.C does not possessed both technical and scale efficiency. It is the least efficient among all Islamic banks in Bahrain.

Next, in Bangladesh there are only two banks available for observations which are Shahjalal Islami Bank Ltd and ICB Islamic Bank Ltd. Based on Table 5, Shahjalal Islami Bank Ltd is a domestic- 
owned bank meanwhile ICB Islamic Bank Ltd is a foreign-owned bank. The result in Table 5 suggests that Shahjalal Islami Bank Ltd is a better performer than ICB Islamic Bank Ltd in terms of technical and pure technical efficiency. However, ICB Islamic Bank Ltd performs slightly better in terms of scale efficiency which is 0.3713 as compared to Shahjalal Islami Bank Ltd with 0.3641 scale efficiency score. With lower average total assets of USD17, 402.4 million as compared to Shahjalal Islami Bank Ltd that is USD45, 091 million, it shows that even larger bank could have lower scale efficiency.

In Iran, overall the Islamic banks have very low average efficiency score except for puree technical efficiency. In terms of technical efficiency, on average most of the banks have obtained very low average score between 0.2293 and 0.2658 . Nonetheless, as the result suggested in Table 5, Bank Tejarat with higher average total assets of USD250, 750.3 million is the best performer in terms of pure technical efficiency that is 0.8890 and the worst performer is Bank Sarmaye which possessed average total assets of USD22,883.04 million with efficiency score of 0.7091. However, Bank Sarmaye has recorded the highest scale efficiency among all the banks in Iran with 0.3594. This indicates that although Bank Sarmaye has low average total assets, but it manages to become the most efficient in managing its resources with minimal cost to produce output. On the other hand, Bank Saderat Iran with average total assets of USD345, 074 million has become the worst performer in terms of technical and scale efficiency that is 0.2293 and 0.26442 respectively.

As for Jordan, there are only two Islamic banks being observed. Jordan Islamic Bank has average total assets of USD1882.1 million that is higher than Jordan Dubai Islamic Bank with only USD169.5 million. This indicates that Jordan Islamic Bank is actually a larger bank than Jordan Dubai Islamic Bank. Despite higher amount of total assets, Jordan Dubai Islamic Bank has perform better than Jordan Islamic Bank in terms of technical, pure technical, and scale efficiency. As seen in Table 5, there is a huge gap in efficiency between Jordan Dubai Islamic Bank and Jordan Islamic Bank especially in terms of technical efficiency and scale efficiency. Jordan Dubai Islamic Bank's technical efficiency score is 0.6414 meanwhile Jordan Islamic Bank is 0.3059. Jordan Dubai Islamic Bank records pure technical efficiency score of 0.7427 while Jordan Islamic Bank is 0.6159. Based on Table 5, it is clear that Jordan Dubai Islamic Bank is more efficient in terms of management as compared to technical. This is proven when it obtains the highest scale efficiency score of 0.8557 compared to Jordan Islamic Bank that is only 0.4958 .

Overall, it appears that Islamic banks in Malaysia are performing well. There are seven Islamic banks being observed in Malaysia. Among the six observed banks, AmIslamic appears to be the most efficient bank in Malaysia where it records the best performer in technical efficiency, pure technical efficiency, and scale efficiency. Meanwhile, Bank Islam Malaysia Berhad is the worst performer although it is the pioneer in Malaysian Islamic banking sector. AmIslamic achieved the maximum score of 1.000 of pure technical scale. According to Kumar and Gulati (2008), the banks attaining PTE scores equal to 1 are known as 'locally efficient' banks. Hence, based on the result, AmIslamic is considered 'locally efficient' bank where it is very efficient in resource utilization. This also indicates that, the inefficiency of AmIslamic Bank is primarily attributed by scale efficiency rather than managerial efficiency.

First National Bank Modaraba has consistently becomes the best performer in Pakistan. It has the highest pure technical efficiency score that is 0.9102. On the other hand, Dubai Islamic Pakistan Bank has become the worst performer in terms of technical efficiency and pure technical efficiency 
that is 0.2512 and 0.7823 respectively. This shows that foreign Islamic bank, although with higher average total assets of USD26, 534.86 million does not necessarily outperform domestic Islamic bank with lower average total assets of USD2081.76 million in Pakistan.

The result suggest that overall, the Islamic banks in Qatar did not perform very well from 20042011. However, the banks are doing well in terms of pure technical efficiency although less than 1, but both banks that are being observed record high pure technical efficiency score. Qatar International Islamic Bank's pure technical efficiency score is 0.9409 meanwhile Qatar Islamic Bank is 0.9035 . This explains that for both banks in Qatar, the inefficiency is due to scale efficiency and not pure technical inefficiency.

Similarly, the Islamic banks in Turkey also did not perform so well except for pure technical efficiency. There are three Islamic banks being examined in this research. All of the banks have very low efficiency score in technical efficiency as well as scale efficiency. With pure technical efficiency of 0.9724, Kuveyt Turk Katilim Bankasi A.S appears as the best performer meanwhile the Islamic bank with the lowest pure technical efficiency is Turkiye Finans Katilim Bankasi AS that is 0.5827 . As for technical efficiency, the Islamic banks in Turkey performs very poorly that is TE between 0.2209 to 0.2586 . This is similar to scale efficiency, of which even the best scale efficiency score is below average. Turkiye Finans Katilim Bankasi AS appears the best performer in terms of scale efficiency that is 0.4439 while the worst performer is Asya Katilim Bankasi that scores only 0.2346. Asya Katilim Bankasi appears to be very inefficient both technical and scale.

In United Arab Emirates, as seen in Table 5, the Islamic bank performs best in terms of pure technical efficiency. Dubai Islamic Bank PLC obtains pure technical efficiency score of 0.8854 that makes it the best performer in UAE meanwhile Tamweel PJSC exhibits the lowest pure technical efficiency score that is 0.5562 . None of the banks in UAE could be described as efficient by looking at the technical efficiency and scale efficiency scores in Table. All of the Islamic banks record low than average score for both technical and scale efficiency.

\section{CONCLUSION}

The empirical findings suggest that during the period of study, pure technical efficiency outweighs scale efficiency in the Global Islamic banking sector implying that the Islamic banks have been managerially efficient in exploiting their resources to the fullest extent. The empirical findings seem to suggest that the Global Islamic banks have exhibited high pure technical efficiency. During the period of study it is found that pure technical efficiency has greater influence in determining the total technical inefficiency of the Global Islamic banking sectors.

Due to its limitations, the paper could be extended in a variety of ways. Firstly, the scope of this study could be further extended to investigate on result that contributes the efficiency during Global Financial Crisis. There is possibility Islamic Bank has prepared for the crisis or there is possibility on migration of consumer confidence from conventional banking system to Islamic banking model during Global Financial Crisis, but studying details of contribution factor during 2006 to 2009 we may find the actual reason that contributed on this factor.

This study will contribute to the growing existing empirical literature on Islamic banking efficiency in the world. The study also is important as it covers all the local Islamic banks in the 
world during the period of study. Furthermore, it has a significant contribution as the scope of the banking sector not really covered by the previous studies. This investigation is likely to be useful to a number of interest groups and policy-makers including the governments of the selected countries, commercial banking authorities, Islamic banking authorities, and the society as well as people are dealing with banks.

\section{ACKNOWLEDGEMENT}

Financial support from Universiti Malaysia Sarawak and Research Acculturation Collaborative Effort RACE/e(3)/1250/2015(06), Ministry of Higher Education Malaysia is gratefully acknowledged. All remaining flaws are the responsibilities of the authors.

\section{REFERENCE}

Ahmad Mokthtar, H.S, Abdullah, N., \& Al-Habshi, S.M. (2007). Technical and Cost Efficiency of Islamic Banking in Malaysia. Review of Islamic Economics, vol.11, no.1.

Ahmad, S. \& Abdul Rahman, A.R. (2012). The Efficiency of Islamic and Conventional Commercial Banks in Malaysia. International Journal of Islamic and Middle Eastern Finance and Management. Research paper, Vol. 5, No. 3, pp.241-263.

Altunbas, Y. \& Chakravarty, S.P. (2001). Frontier Cost Functions and Bank Efficiency. Economic Letters. Research paper, Vol. 72, pp. 233-240.

ASEAN Bankers Association. (2012). About ABA-Overview. Retrieved January 2, 2014, from http://www.aseanbankers.org/about/index.htm

ASEAN Development Bank (2013). The Road to ASEAN Financial Integration: A Combined Study on Assessing the Financial Landscape and Formulating Milestones for Monetary and Financial Integration in ASEAN. Mandaluyong City, Philippines.

Bank Negara Malaysia (2010). Shariah Resolutions in Islamic Finance ( $2^{\text {nd }}$ Eds.). Malaysia.

Efendić, V. (2011). Efficiency of the Banking Sector of Bosnia-Herzegovina with Special Reference to Relative Efficiency of the Existing Islamic Bank. Paper presented at Eighth International Conference on Islamic Economics and Finance, Qatar. Eighteen Banks. Islamic Economic Studies. Researh Paper, 12 (1), 1-19.

Ernst and Young (2011). The World Islamic Banking Competitiveness Report 2011-2012. Dubai, United Arab Emirates.

Ernst and Young (2012). The World Islamic Banking Competitiveness Report 2012-2013. Dubai, United Arab Emirates.

Ernst and Young (2013). World Islamic Banking Competitiveness Report 2013-2014. Dubai, United Arab Emirates.

Haseeb et al. (2010). Efficiencies Comparison of Islamic and Conventional Banks of Pakistan. International Research Journal of Finance and Economics. Research Paper, ISNN 14502887, Iss.49, pp.24-42.

Hassan, M.K. (2005). The Cost, Profit, and X-Efficiency of Islamic Banks. Paper presented at the $12^{\text {th }}$ Annual Conference of the Economic Research Forum, Cairo, Egypt. 
Hassan, M.K. (2006). The X-Efficiency in Islamic Banks. Islamic Economic Studies, Vol.13, No.2.

Hassan, W.M. (2013). Efficiency of the Middle East Banking Sector: A Non-Parametric Approach: A Comparative Analysis between Islamic and Conventional Banks. Business and Management Research. Research paper, Vol. 2, No. 4.

Islamic Financial Services Board (2013). Islamic Financial Services Industry Stability Report 2013.

Johnes, J., Izzeldin, M. \& Pappas, V. (2010). The efficiency of Islamic and conventional banks in the Gulf Cooperation Council (GCC) countries: An analysis using financial ratios and data envelopment analysis. Lancaster University Management School, Working paper 2009/023.

Mariani, A.M., Saal, D.S., \& Battisti, G. (2008). Efficiency in Islamic and Conventional Banking: An International Comparison. Aston Business School. Research Paper, ISBN 978-1-85449733-8, No. 0811.

Mohamad Noor, M.A. \& Nor Hayati, A. (2012). The Determinants of World Islamic Banks' Efficiency: Does Country Income Level Have an Impact? Journal of Islamic Economics, Banking, and Finance. Research Paper, Vol. 8, No. 2 (Apr-Jun).

Mohamad Noor, M.A., \& Nor Hayati, A. (2011). Measuring MENA Islamic Banks Efficiency: Does Country Income Level Have an Impact? Islam and Muslim Societies-a social science journal, Vol. 4, No.2.

Mohamad Noor, M.A., Nor Hayati, A., \& Sufian, F. (2010). The Efficiency of Islamic Banks: Empirical Evidence from the Asian countries' Islamic banking sectors. MPRA Paper, No. 31869 (July, 24).

Mohamad, S., Hassan, T., \& Bader, M.K.I. (2008). Efficiency of Conventional versus Islamic Banks: International Evidence using the Stochastic Frontier Approach (SFA). Journal of Islamic Economics, Banking, and Finance. Research Paper, pp.108-130.

Mokhtar, A., Abdullah, N., \& Al-Habshi, S.M. (2006). Efficiency of Islamic Banking in Malaysia: A Stochastic Frontier Approach. Journal of Economic Cooperation 27, 2(2006), 37-70.

Mostafa, M. (2007). Benchmarking top Arab banks' Efficiency Through Efficienct Frontier Analysis. Industrial Management and Data Systems. Research Paper, Vol. 107, No. 6, pp. 802-823.

Mostafa, M.M. (2011). Modeling Islamic banks' Efficiency : A Non-Parametric Frontier Approach. International Journal of Islamic and Middle Eastern Finance and Management. Research Paper, Vol.4, No.1, pp.7-29.

Nor Hayati, A., Mohamad Noor, M.A., \& Sufian, F. (2010). Measuring Islamic banks Efficiency: the case of world Islamic banking sectors. MPRA Paper, No. 29497 (July, 24).

Onour, I.A. \& Abdalla, A.M.A (2012). Efficiency of Islamic Banks in Sudan: A Non-Parametric Approach. Arab Planning Institute. Working Paper, No. 1012.

Sufian, F., Mohamad, A.M.N., \& Abdul Majid, M.Z. (2008). The Efficiency of Islamic Banks: Empirical Evidence from the MENA and Asian Countries Islamic Banking Sectors. The Middle East Business and Economics Review, Vol.20, No.1.

Tahir, I.M., Abu Bakar, N.M., \& Haron, S. (2011). Evaluating Efficiency of Islamic Banks Using Data Envelopment Analysis: International Evidence. Journal of Islamic Economics, Banking and Finance. Research Paper, Vol. 7, No.1 (Jan-Mar 2011). 
The Edge. (2012). Zeti: Asean on the brink of banking sector integration. Retrieved February 4, 2014, from http://www.theedgemalaysia.com/business-news/224629-zeti-asean-on-thebrink-of-banking-sector-integration.html

Waemustafa, W. (2013). The Emergence of Islamic Banking: Development, Trends, and Challenges. Journal of Business and Management. Research paper, ISSN: 2278-487X, Vol. 7, Iss. 2, pp. 67-71.

Yudistira, D. (2004). Efficiency in Islamic Banking: An Empirical Analysis of

Zainal, N.S. \& Ismail, M. (2012). Islamic Banking Efficiency: A DEA Approach. Paper presented at Third International Conference on Business and Economic Research ( $3^{\text {rd }}$ ICBER 2012), Bandung, Indonesia.

Corresponding Author: Rossazana Ab-Rahim can be reached at rossazana@gmail.com 